\title{
Popular Music and Left-Wing Scottishness
}

Musique populaire et scotticité de gauche

Jeremy Tranmer

\section{(2) OpenEdition}

1 Journals

\section{Electronic version}

URL: http://journals.openedition.org/etudesecossaises/1124

DOI: 10.4000/etudesecossaises. 1124

ISSN: 1969-6337

\section{Publisher}

UGA Éditions/Université Grenoble Alpes

\section{Printed version}

Date of publication: 25 April 2016

Number of pages: 133-149

ISBN: 978-2-84310-324-7

ISSN: 1240-1439

\section{Electronic reference}

Jeremy Tranmer, "Popular Music and Left-Wing Scottishness", Études écossaises [Online], 18 | 2016, Online since 01 January 2017, connection on 15 March 2021. URL: http://journals.openedition.org/ etudesecossaises/1124; DOI: https://doi.org/10.4000/etudesecossaises.1124 


\section{Popular Music and Left-Wing Scottishness}

Popular music, that is "commercially mass produced music for a mass market [...] including the variety of genres variously subsumed by terms such as rock'n'roll, rock, pop, dance, hip-hop, and R\&B” (Shuker, 2001, p. X), has often been downgraded in accounts of political developments in Scotland over the past thirty years. For example, in The Scottish Nation 1700-2000, Tom Devine merely states:

Rock bands like Deacon Blue, the Pretenders and Runrig were emphatically Scottish in style but nevertheless were able to convey their music to a much wider overseas audience. Runrig celebrated Gaelic culture in particular and Scottishness in general to a younger generation of Scots increasingly confident in their own national identity. (2000, p. 608)

Cairns Craig has only mentioned it in passing, although he has suggested that, following the failure of the 1979 referendum on devolution, the energy previously put into political activity was channeled into culture (Craig, 1999, p. 84). According to him, the consequent cultural vitality "gave Scottish people the sense of confidence in themselves and in their own identity that produced the political changes we are now going through" (ibid., p. 86). As an overall explanation of the role of culture in recent developments, this theory is quite attractive. However, the limited interest showed by Devine, Craig and others in popular music is unfortunate and is perhaps symptomatic of a widespread tendency to view it as an inferior form of cultural expression. This article will not judge the artistic quality of the work produced by Scottish musicians in the $1980 \mathrm{~s}$, but it will be based on the assumption that popular music shapes the way many people experience and interpret the world around them, and is therefore of cultural, social and political significance. It will look in detail at how popular music and musicians in the 1980s expressed a sense of Scottishness, suggesting that this has to be seen in the context of opposition to Margaret Thatcher's Conservative governments, as in Scottish popular music at this time national sentiment and antiThatcherism frequently went hand in hand. Songs by the groups Runrig 
and the Proclaimers will be examined, as well as the political actions of bands such as Deacon Blue. It will be argued that the close relationship between popular music and politics in the very late 1980s and early 1990s is a singularly Scottish phenomenon.

Throughout the 1980s, a significant minority of British musicians engaged actively with politics. Most were openly hostile to the Thatcher governments and expressed their feelings in their music. The Specials were critical of youth unemployment in "Ghost Town", Elvis Costello highlighted the consequences of the Falklands War in "Shipbuilding", and the Beat demanded the Prime Minister's resignation in "Stand down, Margaret". Some musicians such as Billy Bragg and Paul Weller of the Style Council (and formerly of the Jam) gave moral and financial support to opposition groups. Hundreds of benefit concerts were organised to support striking miners during the conflict of 1984-85. Musicians also gave their political opinions in interviews published in the New Musical Express and other newspapers and fanzines. This public role was legitimised by the success of humanitarian ventures, such as Band Aid and Live Aid which aimed to raise money to alleviate starvation in Ethiopia. As a consequence, many musicians came to believe that they could mobilise young people and be a force for change. According to the dominant narrative of this period, the year 1987 was a turning point in the relationship between music and politics (Harris, 2003, p. 153; Carlet, 2004, p. 101). Numerous well-known musicians, including Bragg and Weller, participated in the Labour Party's election campaign of that year under the banner of Red Wedge. Labour lost the election, leading to widespread disillusionment among musicians and a decline in politico-musical activity. "[T] he ideological ferocity of the Thatcher period was giving way to an altogether more apolitical climate" (Harris, 2003, p. 153) with the rise of the "Madchester" scene of the late 1980s, spearheaded by the Stone Roses, the Happy Mondays and the Inspiral Carpets and based on ecstasy and dance music. Moreover, the replacement of Margaret Thatcher as prime minister in November 1990 by the less aggressive and divisive John Major deprived musicians of an obvious target for their ire. This version of events certainly has some validity, but it is arguably a very anglocentric vision since musicians in Scotland continued to play a prominent role in politics after 1987.

Scottish musicians, like their English and Welsh counterparts, wrote songs damning aspects of Margaret Thatcher's policies and their consequences for ordinary people. ${ }^{1}$ However, the reaction of many Scottish musicians was clearly rooted in a sense of Scottishness. The use of

1. No songs were written openly praising the Prime Minister and her policies. 
national symbolism in popular music was not something entirely new. In the 1970s, one of the most commercially successful Scottish bands was the Bay City Rollers, whose concerts throughout the United Kingdom were attended by thousands of teenage girls. The members of the band and their fans were also famous for sewing tartan fabric onto their clothes (Percival, 2010, pp. 200-2). "Rollermania" was relatively short-lived, and by the late 1970s the group's popularity had waned. The Glasgow-based post-punk label Postcard Records, which was created in 1979 and wound up in 1981, used tartan imagery in its artwork. The sleeves of singles by groups on the Postcard Label such as Orange Juice, Aztec Camera, and Joseph K (which the label referred to collectively as "The Sound of Young Scotland") featured tartan patterns. This emphasis on the national origins of the label was significant since it was "the first genuinely innovative and successful independent label in Scotland - a label that would work to establish a new perception of music in Scotland for an industry largely focused in London" (Percival, 2010, p. 204). In the early 1980s, the punk group the Skids split up, their guitarist Stuart Adamson forming Big Country. The latter pioneered a new sound based on electric guitars imitating bagpipes. This could be heard, for example, in the introduction to their 1983 single "Fields of Fire (400 Miles)" or on the single "In a Big Country" released in the same year. This distinctive sound became the group's trademark.

These groups were inspired by what historians such as Eric Hobsbawm and Hugh Trevor-Roper termed "invented traditions", in other words elements of national life which were widely assumed to have existed for centuries or since time immemorial but had in fact been adopted at a particular moment of history, often a time of change or crisis. In this case, tartan and bagpipes belonged to the Highlands of Scotland and were adopted as symbols by the whole of Scotland during the nineteenth century (Trevor-Roper, 1997, pp. 15-42). Their exact origins were later forgotten by most people, who simply saw them as national traditions. The Bay City Rollers, Postcard Records and Big Country thus used elements which were clearly recognised, both in Scotland and elsewhere, as being Scottish and had been national symbols for over a century. Interestingly, later in the 1980s, groups adopted different methods to signal their national identity, using references both to the past and the present. The songs "Alba" by Runrig and "Letter from America" by the Proclaimers illustrate this.

The group Runrig was founded in the mid-1970s. The original members were born on the Isle of Skye and spoke Gaelic. The name of the band refers to a Scottish form of land ownership which had slowly died out between the eighteenth century and the very early twentieth century. 
Their first album, entitled Play Gaelic, was released in 1978 and only contained songs in that language, making it the first ever album recorded solely in Gaelic. ${ }^{2}$ Although their following albums contained songs in English, they have continued to record a significant number of Gaelic songs. The band has broached many subjects in its songs, but the vast majority have a direct link with the Western Isles or with Scotland in general, as is suggested by the titles of two of their albums - The Highland Connection and The Cutter and the Clan. The subjects of their songs include the militarisation of the Hebrides ("Tir an airm") at a time when plans were afoot to lengthen Stornaway airport for NATO bombers (Morton, 1991, p. 83), the education given to young inhabitants of the Western Isles ("Fichead Bliadhna"), the impact of unemployment in the Highlands ("The Work Song") and industrial decline in Scotland ("Ravenscraig"). Even love songs such as "Màiri" are set on the Isle of Skye. One of their most popular songs is their cover version of "Loch Lomond", which was later voted as Scotland's greatest song (Reisenleitner, 2014, p. 274). More general songs deal with war ("Protect and Survive") and environmental issues ("Our Earth Was Once Green"), for example. The music to which the lyrics are set is relatively varied. Some of the band's earlier work was clearly influenced by Scottish dance music and featured an accordion and a violin. Bagpipes are present in some songs, along with drums which sound similar to those of a marching band. Consequently, it is somewhat reductive to describe the group simply as a "standard guitar and drums rock band" producing music with a "Celtic feel to it" (Craig, 1997, p. 86). The group quickly established a cult following in the late 1970s, became full-time musicians in 1982 and had achieved success throughout Scotland by the mid-1980s. Despite line-up changes (only the brothers Rory and Callum Macdonald remain from the original members), the group has continued to record and perform, celebrating its fortieth anniversary in 2013.

Politically, the members of Runrig described themselves in the 1980 s as being loosely socialist and nationalist but admitted that differences in emphasis existed between them (Morton, 1991, p. 168). The political convictions of the group could be heard in songs such as "Alba", which was released as a single in 1987 and was also on the album The Cutter and the Clan of the same year. The song is interesting for two reasons. Firstly, it is sung in Gaelic, a language spoken by less than $2 \%$ of the Scottish population. Singing in Gaelic was in itself a political act in the broadest sense of the word since it implied defending a language whose

2. Runrig inspired groups such as Oi Polloi, The Thing Upstairs and Mill a h-Uile Rud to record and perform in Gaelic. They have not, however, encountered the same commercial success as Runrig. 
very existence was under threat from English and Scots and which was increasingly confined to the Western Isles. Runrig showed that it was a living language with contemporary relevance. However, as a result of its minority status, most of those who listened to it, whether on a record or a cassette at home or live at a concert, were unable to understand any of the lyrics, except the title (meaning Scotland), which is also the chorus and is therefore repeated several times. They would have had to read the English version of the lyrics which was printed on the album sleeve. The song might have been potentially divisive, creating a schism between Gaelic-speakers and others, particularly as there is no real tradition in British popular culture of songs in other languages than English being successful. The use of Gaelic could therefore have been a barrier. Yet this was not the case. Gaelic may be a minor feature of Scottish nationalism, but it is something which is specifically Scottish, giving it a certain symbolic significance. The live performance by Runrig of Gaelic songs in Scotland added a national dimension of shared heritage to the sense of unity created during concerts and virtually when people listened to the songs at home. Moreover, the title of the song suggests that it is of interest to all Scottish people, irrespective of their origins and culture.

Another interesting point about "Alba" is the vision of Scotland created by the lyrics. The first verse describes landscapes of Scotland ("I see Scotland of the high mountains / And the empty acres / Flying low across the moorland lochs / the forest and the glens"), while the second concentrates on the "wounding and hollow sight / Here as we reach the end of the century", mentioning "the beautiful soil of the people / Still in the hands of the few", "the wheels of industry at a standstill / And the northern lands wasted", and "the empty house in Edinburgh / Without authority or voice". The song ends on a positive note as the narrator concludes "it is good for me to be here now / As I welcome the warmth / In this land that's as exciting for me today / As it was the day I was born". The lyrics present a positive vision of Scotland based on its physical geography and criticism of inequitable land ownership, economic stagnation, and the absence of a parliament. Although the song does not directly name Margaret Thatcher, the phrase "the wheels of industry at a standstill" clearly refers to the consequences of her governments' policies. In the political and economic context of 1987, this reference would not have gone unnoticed, particularly since in Scotland the Prime Minister was frequently held personally responsible for the nation's economic difficulties (Stewart, 2009, p. 1). The 1980s saw heavy industry (such as coal, steel, and shipbuilding) and manufacturing rapidly contract with job losses not offset by expanding sectors such as high technology. As a result, levels of unemployment and poverty were higher than in other parts of Great 
Britain. The song thus combines national sentiment with contemporary left-wing political commentary.

In 1987, the Proclaimers released "Letter from America". The Proclaimers are two identical twin brothers, Charlie and Craig Reid, who were born in Leith in 1962. They performed with punk bands in the late 1970s and early 1980s, founding the Proclaimers in 1983. Their music is heavily influenced by folk and country. Their first album was mainly acoustic, while on their following albums they were accompanied by a band. "Letter from America" was their first taste of commercial success, and it reached number three in the United Kingdom singles charts. Other hits in the following years include "I'm Gonna Be (500 Miles)" and "King of the Road". Much of their music is clearly rooted in Scottish culture and geography as songs such as "The Joyful Kilmarnock Blues" and "Sunshine on Leith" suggest. The brothers are staunch supporters of the Scottish National Party (SNP) and have openly expressed their feelings in songs such as "Cap in Hand" ("But I can't understand why we let someone else rule our land, cap in hand") and "What do you do?" ("Pat votes the Scots way / Just like her mother / But South always takes all / Just like her brother" ... "What do you do / When democracy fails you"), as well as in interviews (Wells, 1988, p. 27). The band continues to tour and record new material to this day and has been described as "arguably the most influential Scottish recording artists of all time" (Williamson, 2009, p. 56).

A striking characteristic of the group, which is present on "Letter from America" as well as on their other recordings, is that they sing in a Scottish accent. This is highly unusual as most Scottish performers (and British artists in general) tend to adopt a mid-Atlantic accent. This had been challenged in the mid to late-1970s by punk, which encouraged singers to retain their original accents in order to create a certain authenticity and to distinguish themselves from American performers. High-profile punk singers such as Johnny Rotten of the Sex Pistols and Joe Strummer of the Clash sang with English accents and were imitated by others who were influenced by their stance. In the 1980s, Billy Bragg refused to drop his native southern-English accent, while Morrissey of the Smiths retained his Mancunian accent. However, it was more unusual for Scottish singers not to change accents, allowing the Proclaimers to appear original and innovative. This no doubt contributed to the appeal of "Letter from America" both in Scotland, where their approach was seen as a refusal to abandon part of their identity and was celebrated (Fulton, 2013), and in other parts of the United Kingdom, where it was simply a novel feature differentiating them from their contemporaries (Logan, 2007). The Proclaimers also occasionally used Scots in their lyrics. For instance, the song 
"I'm Gonna Be (500 Miles)" contains the verb to haver ("And if I haver, hey, I know I'm gonna be / I'm gonna be the man who's havering to you"), meaning to speak nonsense or to talk incoherently.

The narrator of "Letter from America" wonders what happened to his compatriots who were forced to leave Scotland for North America as a result of the Highland Clearances of the eighteenth and nineteenth centuries ("I've looked at the ocean / Tried hard to imagine / The way you felt the day you sailed / From Wester Ross to Nova Scotia"), before lamenting the impact of their departure on local communities ("Lewis no more / Skye no more / Lochaber no more / Sutherland no more"). The expression "Lochaber no more" had historical and cultural resonance. It was first used in the ballad "Farewell to Lochaber" written by the poet Allan Ramsay in 1724. It recounts the tale of a soldier leaving Scotland to fight in a distant land. The theme of exile was behind John Watson Nicol's 1883 painting Lochaber No More in which a Highland couple could be seen on a ship with their belongings. ${ }^{3}$ The painting expresses the feelings of loss and despair felt by the couple as they left their home land. The narrator of "Letter from America" then moves on to the need to save contemporary Scotland ("I wonder my blood / Will you ever return / To help us kick the life back to a dying mutual friend? / Do we not love her / I think we all tell you about"). The song ends with a list of towns which had recently experienced significant job losses ("Methil no more / Irvine no more / Bathgate no more / Linwood no more"), and is repeated several times. ${ }^{4}$ It echoes the list of areas which had suffered due to the clearances and emigration, creating a clear connection between the past and the present. As in "Alba", no direct reference is made to Margaret Thatcher. The link between suffering in the past and the present was also explicit on the sleeve of the single. The painting Lochaber No More is superimposed on a black and white photograph of an empty factory. It is quite clear that in terms of both form (accent) and content (historical and contemporary references), the song has a number of distinctly Scottish characteristics.

Numerous sociologists and historians of rock music have noted that the meaning of a song is not to be found solely in its lyrics, since they can be received and interpreted in a multitude of different ways (Street, 1986, pp. 153-67). According to Rob Rosenthal and Richard Flacks,

3. The original painting is now part of Fleming Collection of Scottish art held in London and can be seen here: <http://flemingcollection.com/about/nicol-lochaber-no-more-high-res-500dpi/>.

4. The Reid brothers later admitted that they chose those four particular towns simply because they "worked" better in the song than places with longer names which had experienced similar or greater problems (Fraser, 2013). This illustrates the lyrical constraints that exist for songwriters and that impact on the content of their work. 
"[t] he lyrics that most affect a given listener may not necessarily convey the lyrical intent of the artist" (Rosenthal \& Flacks, 2012, p. 110). They give the example of the song "Born in the USA", which Bruce Springsteen had intended as a criticism of the way the American government treated veterans of the Vietnam war. Its hook phrase "Born in the USA" was sufficiently vague to appeal to Ronald Reagan's Republicans who used the song to signal their patriotism. Meaning is widely thought to result from interaction between the song, the performer and the audience, and depends on factors such as the overall sound of the song, how it is performed, and the appearance of the singer (Street, 2001, p. 248). Regarding "Alba" and "Letter from America", the sound of both songs has unmistakably Scottish elements such as language and accent, which listeners cannot fail to hear. As for performance, Runrig frequently sang "Alba" at concerts during which Scottish flags were waved, suggesting that their fans were aware of the nationalist dimension of the group and approved of it. The video of the song, which contained English subtitles, was filmed outside the National Monument of Scotland on Calton Hill overlooking Edinburgh. ${ }^{5}$ The distinctive building was modelled on the Greek Parthenon and was intended to commemorate the Scottish soldiers who had been killed during the Napoleonic Wars. The nearby Royal High School also had political significance since it had been touted as a possible home for a Scottish parliament in the run-up to the 1979 referendum on devolution. The video thus echoed the themes present in the lyrics. Moreover, as Runrig performed at a Red Wedge concert for Labour in Edinburgh in 1986, fans would have recognised the leftwing elements present in "Alba" and in their music in general. The Proclaimers filmed a video for "Letter from America" which shows them singing and marching through a derelict factory. ${ }^{6}$ They are accompanied and surrounded by a large number of ordinary people. The scene is reminiscent of a demonstration of people who have lost their jobs or members of a community whose very existence is under threat, as were those mentioned at the end of the lyrics of the song. It is interspersed with black and white pictures of poverty in the Highlands and emigration, which contrast sharply with the colour image of a young girl representing a resuscitated Scotland. The video thus illustrates the lyrics of the song in a relatively straightforward manner. Finally, the physical appearance of the members of both groups is noteworthy. Many successful male bands of the time, for example Duran Duran and Spandau Ballet, gave a

5. See $<$ www.youtube.com/watch?v=FIjBcSQkMYE $>$.

6. The video can be found here: <www.youtube.com/watch?v=AFm_Ir2_P1s >. 
great deal of importance to their appearance, wearing expensive clothes and sporting fashionable haircuts. Other male performers including the Housemartins (with whom the Proclaimers had toured in 1986) rejected this type of image and adopted a deliberately unpretentious look of jeans, cardigans and denim jackets. The Proclaimers were clearly part of this trend, as can be seen in the video of "Letter from America". Runrig also rejected fashionable attire and wore clothes which were not ostentatious. In addition, neither the Proclaimers nor Runrig were known for having an extravagant lifestyle and appeared overall to be little different to the members of their audience. As a result of the combination of these factors, it can be argued that "Alba" and "Letter from America" would have been seen as embodying a left-wing Scottishness, that is a sense of a distinct national identity incorporating left-wing values.

It is important to bear in mind that not all Scottish groups felt the need or urge to express national sentiment or to criticise, directly or indirectly, the Thatcher governments. This was the case of Altered Images, the Cocteau Twins, Fairground Attraction and Teenage Fan Club, while the Bluebells sang orthodox love songs in an American accent (for example, "Cath"). Furthermore, national questions were not always a priority for Scottish artists who took an active interest in political issues. For instance, Jimmy Somerville of Bronski Beat and later the Communards supported the Labour Party and was active in the struggle for gay rights, while Orange Juice and Aztec Camera played at benefit concerts for the miners. However, they were not vocal about the situation of their home nation. Yet it is striking that a significant number of Scottish artists were prepared to nail their colours to the mast, even after the Conservatives' victory in the 1987 general election. As mentioned above, many English musicians lost interest in politics following Margaret Thatcher's third successive victory. In Scotland, this was not the case. This is not to suggest that Scottish musicians were fundamentally more left-wing or politically aware than their English counterparts. Didier Revest has pointed out that it is important to beware of representations of the Scottish as being further to the left than the English and to avoid making generalisations which ignore similarities between the two nations as well as differences within each nation (Revest, 2013, pp. 91-115). As mentioned above, for example, not all Scottish performers expressed their political opinions in public during the 1980s and 1990s. They cannot, therefore, be seen as a homogeneous social group. Nevertheless, it is striking that Billy Bragg is one of the few relatively well-known English musicians to have taken an active interest in politics following Margaret Thatcher's third election victory, whereas many performers who were household names in Scotland continued to do so. This situation can partly be explained by the fact that Red Wedge 
was mainly an English phenomenon. It had been founded to mobilise young people in support of Labour and had organised a tour of marginal constituencies during the election campaign. Few concerts were held in Scotland since the position of the Labour Party was much stronger there than in England (although some Scottish musicians including Jimmy Somerville and Lloyd Cole participated in Red Wedge concerts in England). Moreover, although Labour's overall results were disappointing, they actually improved considerably more in Scotland than in the rest of Great Britain. Anti-Thatcher musicians in Scotland were in synch with a greater number of their compatriots than their comrades in England. Consequently, disillusionment and demobilisation were not as great as in England. In addition, Scottish reactions to the election results were influenced by purely national factors. Although only a minority of Scottish voters had chosen the Conservatives, Margaret Thatcher was reelected due to the strength of her support in England. The "democratic deficit" resulting from Scotland's constitutional status in Great Britain became a central political issue in the following years, as did the flat-rate Community Charge, or Poll Tax, which was implemented in Scotland in 1989, a year earlier than in England. Musicians who lived in Scotland were thus directly concerned and forced to consider their attitude to the Poll Tax before their counterparts in England. The sense of injustice expressed by musicians again combined a feeling of national difference and left-wing sentiment (in the form of opposition to the regressive nature of the tax).

Significantly, the only two songs specifically about the tax were recorded by Scottish bands - "Soul Crying Out" by Simple Minds ("I feel them coming / So close behind / Sister says, we're next in line / The man he says, that's OK / And the Government says you're gonna pay, pay, pay / And you pay / Still you pay") and "Don't Pay the Poll Tax" by The Exploited ('It's comin' through your letter box / A sheet for you to fill in / You know you have to do it / Cause you know you just can't win / Don't pay the poll tax / Stick it up her arse"). In 1989, at the height of the campaign against the tax, a "Rock Against the Poll Tax" concert was held in Edinburgh (Quantick, 1989, p. 50). Organised by the Scottish Trades Union Congress, it was clearly intended as a national protest, and only Scottish bands were invited to perform at it. Deacon Blue, Hue and Cry, the Silencers, Texas, and Wet Wet Wet played at the concert. Some Scottish musicians were also prepared to make individual political statements. In an interview in the New Musical Express, Jim Kerr of Simple Minds railed against the "immoral" nature of the new tax (Staunton, 1989, p. 32), while Stuart Adamson of Big Country described it as "unfair, appalling and repressive" (Collins, 1990, p. 11). In June 1990, a huge outdoor concert (the "Big Day") was put on in Glasgow as part of the capital of cul- 
ture celebrations. Before performing, the singer of Deacon Blue, Ricky Ross, gave a passionate speech in which he highlighted the consequences of the Conservative government's policies on Scotland and condemned Scottish Labour MPs for their muted opposition. His words were cheered by many of those present and heard by millions of Scottish people since approximately 300,000 were present at the event, and it was shown live on television. ${ }^{7}$ They were also reported in the British music press (McKay, 1990, p. 48). However, musicians were divided about how to fight against the Poll Tax. Some such as Stuart Adamson refused to break the law and agreed to pay (Collins, 1990, p. 11), while others including Charlie and Craig Reid of the Proclaimers (Martin, 1990, p. 15), Pat Kane of Hue and Gry (Kane, 1989, p. 139), and Martin Metcalf of Goodbye Mr Mackenzie (Kelly, 1990, p. 3) refused to pay and were prepared to go to prison. The relationship between activists and musicians created during the campaign contributed to the staging in July 1990 of a concert in favour of devolution, "A Day for Scotland", which featured Runrig, Hue and Cry, and the Shamen. The groups mentioned above were important artists in the late 1980s, who had nothing to gain commercially by being associated with political campaigns. The latter tend to be more controversial and divisive than humanitarian or charity work. It can thus be assumed that they were acting out of political conviction.

Through their activities (songs, concerts, and statements), Scottish musicians were performing a particular sense of Scottishness. It was not simply based on history, but it also resulted from moral indignation at the consequences of Margaret Thatcher's policies on Scotland and an impression of difference from England due to the specifically Scottish experience of Thatcherism. Some concluded that devolution was the solution to Scotland's problems, while others came to favour independence. Pat Kane and Ricky Ross had both voted Labour in 1987 and remained attached to left-wing values, but they switched their allegiance to the SNP by the end of the decade. Charlie Reid later stated that his experience of the Thatcher years had reinforced his belief in socialism and converted him to nationalism (Rennie, 2013). To a certain extent, Scottish musicians were representative of significant sections of Scottish society, including some with an active involvement in politics. A growing sense of the singularity of the Scottish experience of Thatcherism and of the state of Scottish politics led many in the labour movement to question their

7. An indication of the atmosphere at the Big Day was given by the reception reserved for the singer Sheena Easton. Easton was born near Glasgow but had moved to the United States following her first British chart success in the early 1980s. Her newly-adopted mid-Atlantic accent went down badly with many of those present at the Big Day who booed and jeered her (English, 2010). 
previous hostility to devolution and independence, as well as their relationship to English politics. This process was not limited to the Labour Party. In 1991, the Communist Party of Great Britain changed its organisation and ideology, becoming Democratic Left. In a significant break with the past, it adopted a federal structure, with Democratic Left Scotland having a great deal of autonomy. Scottish Communists who were opposed to these changes created their own grouping, the Communist Party of Scotland. In the same year, members of the Militant Tendency who had been expelled from the Labour Party created Scottish Militant Labour as an autonomous structure. Leading figures within the organisation such as Tommy Sheridan began to stress the long-term aim of creating an independent socialist Scotland. Members of these groupings went on to found the Scottish Socialist Party later in the decade. Moreover, from the end of the 1980s, the SNP increasingly positioned itself to the left of the Labour Party, as it became clear when it advocated non-payment of the Poll Tax, whereas Labour adopted a more moderate position. In doing so, it succeeded in attracting traditional Labour voters, for example at the Glagow Govan by-election of 1988 when its candidate overturned a large Labour majority to win the seat (Duclos, 2014, p. $43-6)$.

It is notoriously difficult to measure the impact of a song or a group with any accuracy. However, as John Street has stated, pop music does not simply reflect the politics of a particular period since it can also establish "a context through which politics is viewed and judged" (Street, 2001, p. 247). It could thus be argued that the activities of musicians contributed to shaping developments in Scottish society. In the late 1980s, groups such as the Proclaimers, Runrig and Deacon Blue appealed mainly to the young, a constituency which tended to be unreceptive to traditional party politics and propaganda. Left-wing Scottishness was an integral part of these bands, which could not be missed by the young people who bought their records and attended their concerts in huge numbers. Their commercial success would suggest that Scottish young people identified with them, at least to a certain extent. It is therefore likely that musicians contributed to shaping young people's worldviews by strengthening their sense of national belonging and providing a political vision of Scotland's situation.

Furthermore, the activities of the Scottish musicians in question can be seen as examples of what Michael Billig has termed "banal nationalism". According to Billig, the constant "flagging" of nationhood by "routine and familiar forms" ensured that the members of a nation were constantly reminded of their national identity and did not forget it (Billig, 2014, p. 93). He mentions, for example, the national framework within 
which the news is presented on television and in the press and refers to the constant use of "we" by politicians and the media to signify shared membership of the British nation (Billig, 2014, p. 94). He incorporates these elements into a broad definition of nationalism, suggesting that the latter is present in the everyday lives of citizens of all nations and not simply on special occasions. Tim Edensor has noted that theorists of nationalism tend to concentrate on high culture and that their work consequently lacks "a sense of the unspectacular, contemporary production of national identity through popular culture and in everyday life" (Edensor, 2012, p. 12). He examines sports, carnivals and cars and brings out their significance for national identity, but he does not look specifically at popular music. Nevertheless, his basic approach, along with that of Billig, can be applied to the Scottish musicians mentioned above. Their frequent inclusive references to Scotland were a constant reminder to young Scots of who they were and what nation they belonged to. This was particularly important in the late 1980s and early 1990s, a time of economic and social change and political impasse. Songs were not only listened to by those who bought records by Runrig and the Proclaimers, for example, since they were played on television and on the radio. It must also be borne in mind that at the time there were relatively few television channels and radio stations (since specialist channels and stations had not yet appeared). As a result, they attracted a broad cross-section of the population. Songs which were played on them therefore reached a sizeable audience. The songs of Runrig and the Pretenders therefore flagged national identity in many homes and places of work, as well as in concert venues. Scottish national identity was thus present in places that were central to the everyday lives of many people.

Many Scottish musicians played a prominent public role in the late 1980s and early 1990s, which is in itself, indicative of the growing cultural and political singularity of Scotland. Scottish musicians opposed the Conservatives from a distinctly left-wing national perspective, and supported changes in Scotland's constitutional status. Like mainstream artists in the rest of Great Britain, they were less present in public life in the following years. Nevertheless, in 1997, Donnie Monro of Runrig left the band to contest the Ross, Skye and Inverness parliamentary seat for the Labour Party, while in 2001, Pete Wishart also left the group to stand as an SNP candidate in the Tayside North constituency. Unlike Monro, he was successfully elected to Westminster. Musicians reappeared during the 2014 referendum campaign. Although there were no national concerts, prominent musicians did not hesitate to express their opinions. For instance, Donnie Monro, Shirley Manson (Garbage) and Sharleen Spiteri (Texas) stated their opposition to independence, while the Reid 
brothers, Ricky Ross, Pat Kane and Alex Kapranos (Franz Ferdinand) announced that they were going to vote in favour of it. ${ }^{8}$ The Proclaimers went one step further and donated $£ 10,000$ to the "yes" campaign (Brooks, 2014). Moreover, politically-minded music lovers launched a campaign to ensure that the Proclaimers" "Cap in Hand" topped the download charts the week of the referendum (Macnab, 2014). It is noteworthy that a number of the musicians who gave their opinions in 2014 had already engaged with politics in the late 1980s, creating an element of continuity between the two periods. However, the common ground that existed between them as a result of their opposition to Thatcherism no longer existed, and some of them found themselves on different sides of the fence during the referendum campaign.

\section{Bibliography}

BILlig Michael, 2014 [1995], Banal Nationalism, London, SAGE Publications.

Bowler Dave \& Dray Bryan, 1995, Deacon Blue. Just What I Feel, London, Sidgwick \& Jackson.

Brooks Libby, 2014 (2 September), "The Proclaimers Donate $£ 10,000$ to Scotland's Yes Campaign", Guardian. Available on <http://www. theguardian.com/politics/2014/sep/02/proclaimers-donate-scotlandyes-campaign $>$.

CAarlet Yasmine, 2004, Stand Down Margaret, Clermont-Ferrand, Éditions Mélanie Séteun.

Coluins Andrew, 1990 (21 April), "Are Pop Stars Revolting?", New Musical Express, p. 11.

—, 1998, Still Suitable for Miners. Billy Bragg: The Official Biography, London, Virgin Books.

Cosgrove Stuart, 1987 (1 August), "Family at War", New Musical Express, p. 13.

Craig Cairns, 1999, "(Re)-Defining Scottish Nationalism after Devolution. disClosure interviews Cairns Craig", disClosure: A fournal of Social Theory, vol. 8, pp. 81-100.

Denselowe Robin, 1989, When The Music's Over. The Story Of Political Pop, London, Faber and Faber.

Devine Tom M., 2000 [1999], The Scottish Nation: 1700-2000, London, Penguin.

8. English musicians including David Bowie and Paul McCartney lent their support to the "no" campaign. 
Duclos Nathalie, 2014, L'Écosse en quête d'indépendance. Le référendum de 2014, Paris, Presses de l'université Paris-Sorbonne.

Edensor Tim, 2002, National Identity, Popular Culture and Everyday Life, Oxford, Berg.

English Paul, 2010 (31 May), "The Big Day - 20 years On: Stars and Fans Remember Historic Scots Gig", Daily Record. Available on <www. dailyrecord.co.uk/entertainment/music/music-news/the-big-day---20years-1060433>.

Fraser Douglas, 2013 (13 October), "Bathgate No More, Linwood No More", BBC News. Available on <www.bbc.com/news/uk-scotlandscotland-business-24509655>.

Frith Simon \& Street John, 1992, "Rock Against Racism and Red Wedge: From Music to Politics, from Politics to Music", in R. Garofol (ed.), Rockin' the Boat. Mass Music and Mass Movements, Cambridge, MA, South End Press, pp. 67-80.

Fulton Rick, 2013 (5 July), "The Proclaimer Look Back at 25 Years in the Business Ahead of Their Opening Slot at T in the Park", Daily Record. Available on <www.dailyrecord.co.uk/entertainment/music/ music-news/proclaimers-look-back-25-years-2026746>.

Hassan Gerry, 2014, Independence of the Scottish Mind: Elite Narratives, Public Spaces and the Making of a Modern Nation, London, Palgrave Macmillan. Harris John, 2004 [2003], The Last Party. Britpop, Blair and the Demise of English Rock, London, Harper Perennial.

Kane Patrick, 1989 (24 June), "A Hitch on the Bandwagon”, The Scotsman, in P. Kane, 1992, Tinsel Show. Pop, Politics, Scotland, Edinburgh, Polygon, pp. 139-42.

Kelly Danny, 1987 (20 June), "Love's Lost Labour", New Musical Express, p. 6.

_, 1990 (17 March), "Mac Poll-Axed", New Musical Express, p. 3.

Logan Brian, 2007 (8 February), "Pop Idols", Guardian. Available on <www.theguardian.com/uk/2007/feb/08/britishidentity.musicnews $>$.

Lynsky Dorian, 2010, 33 Revolutions Per Minute. A History of Protest Songs, London, Faber and Faber.

Macnab Scott, 2014 (2 September), "Scottish Independence: Proclaimers Song Tops Charts", The Scotsman. Available on <www.scotsman.com/ what-s-on/music/scottish-independence-proclaimers-song-topschart-1-3527999>.

Martin Gavin, 1990 (24 November), "Twin Geeks", New Musical Express, pp. 14-15.

MaKaY Alistair, 1990 (16 June), "The Big Day", New Musical Express, p. 48. 
Morton Tom, 1991, Going Home. The Runrig Story, Edinburgh, Mainstream Publishing Company.

Percival J. Mark, 2010, "Rock, Pop and Tartan", in I. Brown (ed), From Tartan to Tartanry: Scottish Culture, History and Myth, Edinburgh, Edinburgh University Press, pp. 195-211.

Quantick David, 1989 (15 April), "Never Mind the Pollocks", New Musical Express, p. 50.

Reisenleitner Markus, 2014, "Runrig's Celtic Revival: Folk-Rock, the Gaelic Language, and the Cultural Politics of the Scottish Islands", in C. Glanz and A. Mayer-Hirzberger (eds), Musik und Erinnern: Festschrift für Cornelia Szabó-Knotik, Vienna, Hollitzer, pp. 273-85.

Rennie Allan, 2013 (9 April), "Proclaimers Star Charlie Reid Said Thatcher's Politics Made Him Back Scottish Independence", Daily Record. Available on <www.dailyrecord.co.uk/news/scottish-news/pro claimers-star-charlie-reid-said-1819483>.

Revest Didier, 2013, "Homo Anglicus / Homo Scotus: The Naturalisation of England and Scotland in Scottish Political, Economic and Social Discourse in Recent Times", Études écossaises, n 6, pp. 91-115.

Rosenthal Rob \& Flacks Richard, 2012, Playing for Change. Music and Musicians in the Service of Social Movements, Boulder, Paradigm Publishers. Shuker Roy, 2001 [1994], Understanding Popular Music, London, Routledge. Sked Alan \& Cook Chris, 1993 [1979], Post-War Britain. A Political History, London, Penguin.

Skinner Sawyers June, 1994, "A New Day Dawning: The Struggle for National Identity in Contemporary Scottish Song", International Review of Scottish Studies, vol. 19. Available on <www.synergiescanada.org/ fr/journals/ont/irss/70/597>.

Staunton Terry, 1989 (4 February), "Street Fighting Man", New Musical Express, pp. 26-27, 32.

Stewart David, 2009, The Path to Devolution and Change. A Political History of Scotland under Margaret Thatcher, London, Tauris Academic Studies.

Street John, 1986, Rebel Rock. The Politics of Popular Music, Oxford, Basil Blackwell.

—, 2001, "Rock, Pop and Politics", in S. Frith, W. Straw and J. Street, Cambridge Companion to Pop and Rock, Cambridge, CUP, pp. 243-55.

Trevor-Roper Hugh, 1997 [1983], "The Invention of Tradition: The Highland Tradition of Scotland", in E. Hobsbawm and T. Ranger (eds), The Invention of Tradition, Cambridge, Cambridge University Press, pp. 15-42.

Wells Steven, 1988 (20 August), "The Ballot or the Bullet", New Musical Express, pp. 26-7. 
Whytock Lisa, n.d., "Resisting the Poll Tax", Yeah! Deacon Blue Magazine, 4, pp. 18-19.

Williamson Kevin, 2009, "Language and Culture in a Rediscovered Scotland", in M. Perryman (ed), Breaking Up Britain: Four Nations after a Union, London, Lawrence \& Wishart, pp. 53-67. 